\title{
Effects of Maltose on Insulin Secretion in Perfused Rat Pancreas
}

\author{
Takayoshi Toyota*, Yoshiniro Ando, Hiromi Nishimura \\ and Yukimasa Hirata \\ The First Department of Internal Medicine, Tottori University \\ School of Medicine, Yonago
}

Toyota, T., Ando, Y., Nishmura, H. and Hirata, Y. Effects of Maltose on Insulin Secretion in Perfused Rat Pancreas. Tohoku J. exp. Med., 1971, 104(4), 325330 — In this study effect of maltose on the insulin secretion from the rat pancreas was examined according to the perfusion method of Anderson and Grodsky. Solution of Krebs-Ringer bicarbonate buffer containing bovine albumin in four per cent was used as the perfusate. The solution of glucose, maltose, sucrose or lactose was perfused for 30 minutes. No effect of of maltose, sucrose or lactose $(400 \mathrm{mg} / 100 \mathrm{ml})$ on the insulin secretion from the perfused rat pancreas was obtained, although glucose $(400 \mathrm{mg} / 100 \mathrm{ml})$ stimulated the insulin secretion. These results suggested that maltose was not metabolized enough to release the insulin in the $\beta$-cells of the rat pancreas. —— insulin; pancreas perfusion; maltose.

Maltose is hydrolyzed to glucose by maltase in the intestinal cells, when it is orally administered. Weser et al. (1967) and Bittencourt et al. (1969) reported that maltose was, however, directly metabolized in the tissues, when maltose was parenterally administered in man and rats, and that there was the activity of maltase in the intestine, kidney, brain, liver, serum and pancreas of rats. Young and Weser (1970) obtained the conclusion that circulating glucose and maltose were similarly metabolized and that insulin effected a more rapid oxidation of glucose and maltose. They suggested that maltose metabolism proceeded via hydrolysis to glucose. These reports indicate that maltose is useful in the therapy of diabetes mellitus as fuels of carbohydrates. It is, however, unknown whether maltose stimulates the insulin secretion from the pancreas or not.

This study was performed in order to examine an insulin releasing effect of maltose using the perfused rat pancreas in vitro.

\section{Methods and Materials}

Male Wistar albino rats weighing 300 to $360 \mathrm{~g}$ were fasted for 20 hours before operation. They were anesthetized with Nembutal $(20 \mathrm{mg} / \mathrm{kg})$. Preparation of the isolated pancreas was performed according to the method of Anderson and Long (1947) and Grodsky et al. (1963). The abdominal cavity was opened through a midline incision, and the mesenteric artery was ligated. The omentum joining the patcreas and the transverse colon was separated by

Received for publication, January $8,1971$.

* Present address: The Third Department of Internal Medicine, Hirosaki University School of Medicine, Hirosaki, Japan. 
blunt dissection and the entire intestine below the duodenum was removed. The esophagus was ligated and cut above the ligature. The aorta was exposed through the crura of the diaphragm above the point of origin of the celiac artery. After the intravenous injection of heparin ( $500 \mathrm{U}$ ) into the vena cava, the aorta was cut and the preparation was lifted out of the abdomen. Ligature were tied around the portal vein, the hepatic artery and the choledochus and cut above the ligature.

The preparation was removed together with the stomach, spleen, pancreas and duodenum (Fig. 1). An arterial cannula was inserted into the celiac artery and tied in place. A venous cannula was inserted into the end of the portal vein. Perfusion through the preparation was initiated several minutes after isolation of the preparation.

The perfusion apparatus for this study was made according to Sussman et al. (1966) (Fig. 2). The perfusate was pumped to a glass lung for oxygenation from the reservoir and then pumped to the arterial cannula. The perfusate flowed through the pancreas

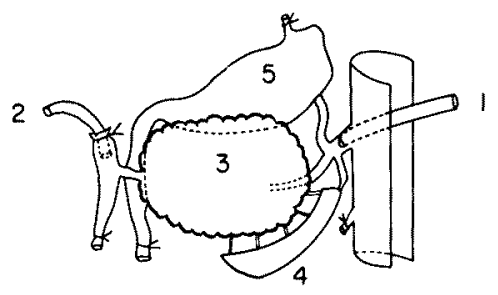

Fig. 1. Diagram of preparation of the rat pancreas.

1, Arterial cannula. 2, Portal cannula. 3, Pancreas. 4, Spleen. 5, Stomach.

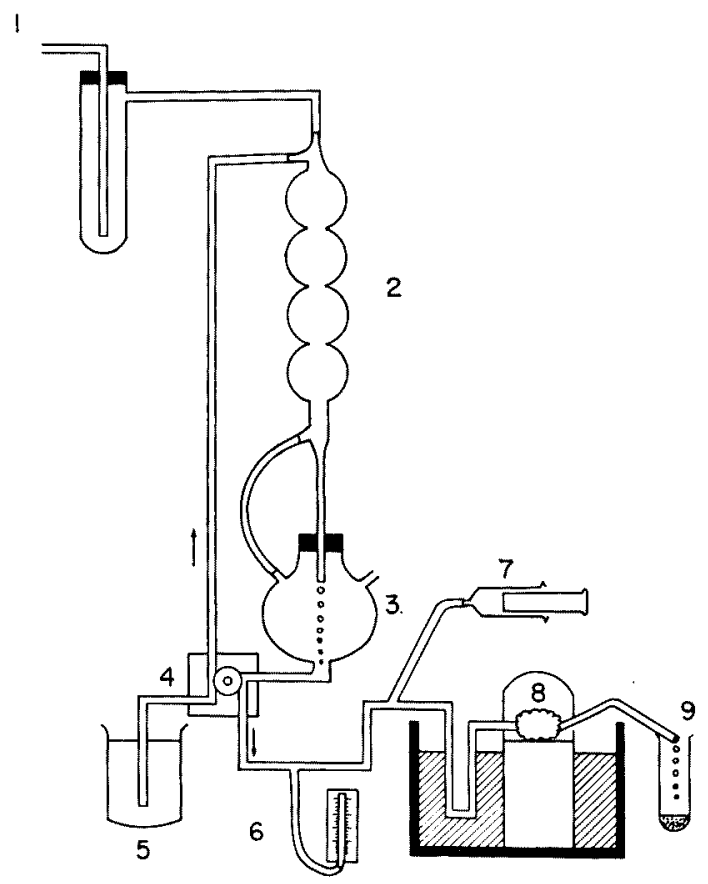

Fig. 2. Diagram of apparatus of perfusion.
1, Oxygen.
2, Glass lung.
3, Reservoir.
4, Pump.
5, Solution.
6, Manometer.
7 , Side arm syringe.
8, Isolated pancreas.
9, Effluence. 
and exited from the portal vein. The perfusion apparatus was kept at a constant temperature of $37^{\circ} \mathrm{C}$ by adjustment of the thermostat. Flow rate through the pancreas was usually $5 \mathrm{ml} / \mathrm{min}$ at perfusion pressure of about $60 \mathrm{~mm} \mathrm{Hg}$. The venous effluence was collected per two minutes without recirculation and stored immediately in the freezer at $-20^{\circ} \mathrm{C}$ until the assay. Glucose was measured by the method of glucose oxidase (Teller, 1956) and insulin was measured by the method of Morgan and Lazarow (1962). Rat insulin was used as a standard for the insulin assay.

Standard perfusate consisted of Krebs-Ringer bicarbonate buffer containing bovine albumin in four per cent and $100 \mathrm{mg} / 100 \mathrm{ml}$ of glucose. Standard perfusion was carried out for $\mathbf{1 5}$ minutes in order to stabilize the insulin secretion from the perfused rat pancreas.

1) After the stabilization, glucose solution $(400 \mathrm{mg} / 100 \mathrm{ml})$ or maltose solution (400 $\mathrm{mg} / 100 \mathrm{ml})$ containing glucose $(100 \mathrm{mg} / 100 \mathrm{ml})$ was perfused for 30 minutes to the isolated pancreas of four rats.

2) Sucrose $(400 \mathrm{mg} / 100 \mathrm{ml})$ or lactose solution $(400 \mathrm{mg} / 100 \mathrm{ml})$ containing glucose (100 mg/100 ml) was perfused for 30 minutes to the isolated pancreas of rat.

3) After maltose solution $(400 \mathrm{mg} / 100 \mathrm{ml})$ containing glucose $(100 \mathrm{mg} / 100 \mathrm{ml})$ was perfused for 30 minutes, tolbutamide solution $(5 \mathrm{mg} / \mathrm{ml})$ was infused for 5 minutes through a side arm syringe.

4) Glucose solution $(1,000 \mathrm{mg} / 100 \mathrm{ml})$ was perfused for 20 minutes after maltose solution $(1,000 \mathrm{mg} / 100 \mathrm{ml})$ containing glucose $(100 \mathrm{mg} / 100 \mathrm{ml})$ had been flowed for 20 minutes.

5) Glucose solution $(400 \mathrm{mg} / 100 \mathrm{ml})$ was perfused for 30 minutes after maltose solution $(400 \mathrm{mg} / 100 \mathrm{ml})$ containing glucose $(100 \mathrm{mg} / 100 \mathrm{ml})$ had been flowed for 30 minutes.

\section{Results}

The insulin secretion increased gradually from the isolated pancreas of four rats

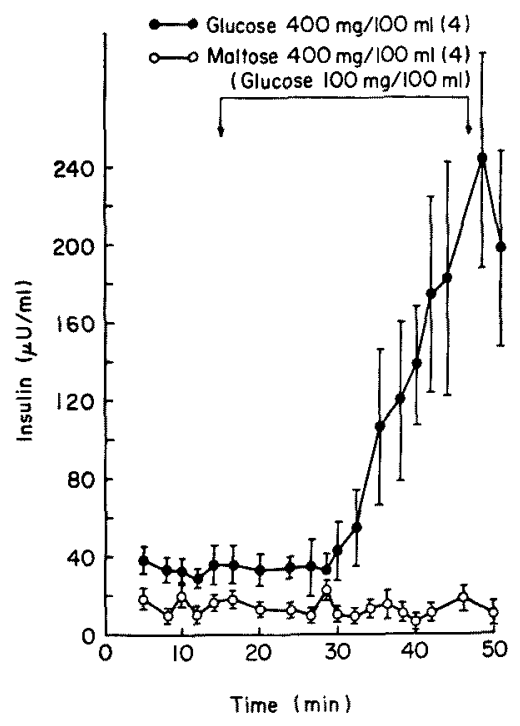

Fig. 3.

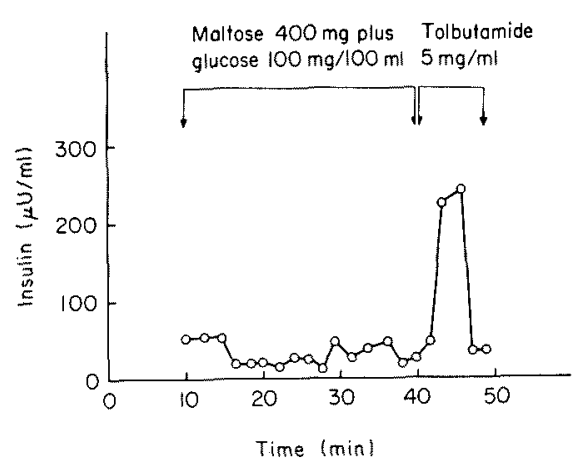

Fig. 4.

Fig. 3. Insulin secretion from the isolated pancreas of four rats, when glucose solution $(400 \mathrm{mg} / 100 \mathrm{ml})$, or maltose solution $(400 \mathrm{mg} / 100 \mathrm{ml})$ containing glucose $(100 \mathrm{mg} / 100$ ml) was perfused for 30 minutes. Arrows indicate the start and end of perfusion with glucose or maltose, respectively.

Fig. 4. Tolbutamide solution $(5 \mathrm{mg} / \mathrm{ml})$ stimulated insulin secretion from the isolated pancreas after maltose solution $(400 \mathrm{mg} / 100 \mathrm{ml})$ containing glucose $(100 \mathrm{mg} / 100 \mathrm{ml})$ was perfused for 30 minutes. 
15 minutes after the beginning of perfusion of glucose solution $(400 \mathrm{mg} / 100 \mathrm{mg})$. The peak of insulin reached the value of $250 \pm 56.2 \mu \mathrm{U} / \mathrm{ml}$ (Fig. 3). On the contrary, the insulin secretion was not stimulated by maltose solution $(400 \mathrm{mg} /$ $100 \mathrm{ml}$ ) containing glucose $(100 \mathrm{mg} / 100 \mathrm{ml})$ in four cases (Fig. 3).

Tolbutamide stimulated the insulin release from the perfused rat pancreas, although glucose solution $(400 \mathrm{mg} / 100 \mathrm{ml})$ did not stimulate the insulin secretion after maltose solution $(400 \mathrm{mg} / 100 \mathrm{ml})$ containing glucose $(100 \mathrm{mg} / 100 \mathrm{ml})$ had been perfused for 30 minutes (Figs. 4 and 5 ).

The solution of $1,000 \mathrm{mg}$ of maltose $/ 100 \mathrm{ml}$ containg glucose $(100 \mathrm{mg} / 100 \mathrm{ml})$ did not stimulate the insulin secretion from the isolated rat pancreas. After that, glucose solution $(1,000 \mathrm{mg} / 100 \mathrm{ml})$ did not stimulate the insulin secretion (Fig 6).

Figs. 7 and 8 showed that the insulin secretion by sucrose or lactose solution $(400 \mathrm{mg} / 100 \mathrm{ml})$ containing glucose $(100 \mathrm{mg} / 100 \mathrm{ml})$ was not obtained.

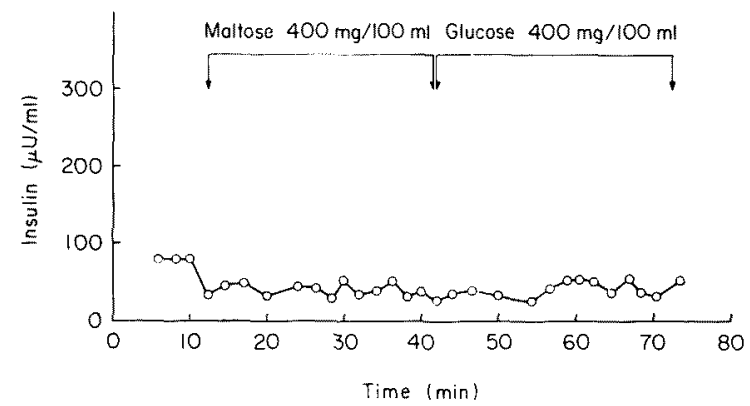

Fig. 5. Insulin secretion was not stimulated during 30 minutes by the perfusion of glucose solution $(400 \mathrm{mg} / 100 \mathrm{ml})$, after matlose solution $(400 \mathrm{mg} / 100 \mathrm{ml})$ containg glucose $(100 \mathrm{mg} / 100 \mathrm{ml})$ had been perfused for 30 minutes.

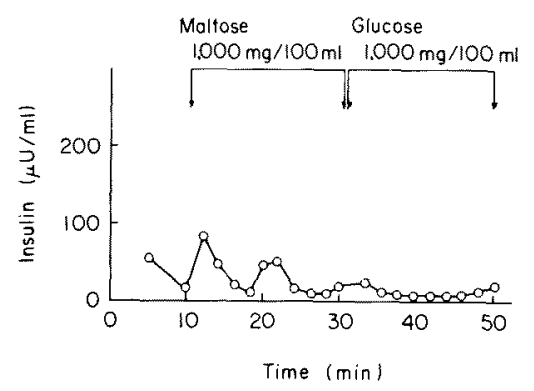

Fig. 6.

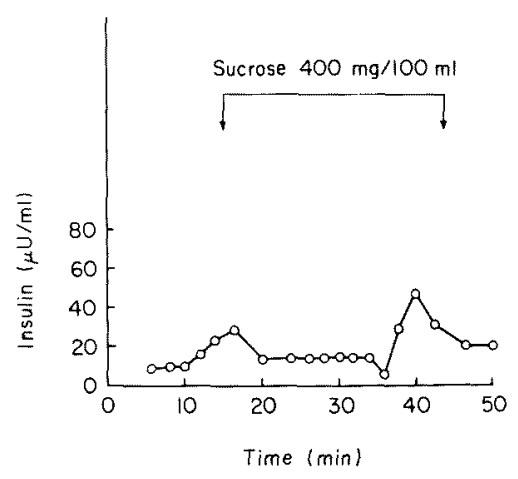

Fig. 7.

Fig. 6. Glucose solution $(1,000 \mathrm{mg} / 100 \mathrm{ml})$ did not stimulate the insulin secretion after maltose solution $(1,000 \mathrm{mg} / 100 \mathrm{ml})$ containing glucose $(100 \mathrm{mg} / 100 \mathrm{ml})$ had been perfused for 20 minutes.

Fig. 7. Insulin secretion was not stimuluated by the perfusion of sucrose solution ( $400 \mathrm{mg} /$ $100 \mathrm{ml})$ containing glucose $(100 \mathrm{mg} / 100 \mathrm{ml})$. 


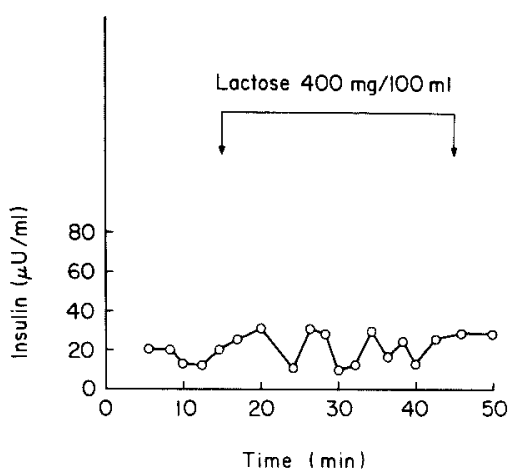

Fig. 8. Insulin secretion was not stimuluated by the perfusion of lactose solution ( $400 \mathrm{mg}$ / $100 \mathrm{ml})$ containing glucose $(100 \mathrm{mg} / 100 \mathrm{ml})$.

\section{Discussion}

Weser et al. (1967) have shown that parenterally administered maltose is not largely excreted in the urine in the rat. Furthermore, parenterally administered maltose in the rat is oxidized to $\mathrm{CO}_{2}$ as completely as glucose. Young and Weser (1970) reported that circulating glucose and maltose were similarly metabolized and that insulin effected a more rapid oxidation of glucose and maltose. It is interesting that there is maltase in the pancreas of the rat. This result, however, does not definitely reveal that maltose is utilized in the pancreas of the rat, especially in the $\beta$-cells of the pancreas.

Our study has shown that maltose $(400 \mathrm{mg} / 100 \mathrm{ml})$ does not stimulate the insulin secretion from the perfused rat pancreas (Fig. 3). Maltose in concentration of $1,000 \mathrm{mg} / 100 \mathrm{ml}$ does not stimulate the insulin secretion (Fig. 6). These results suggest that maltose is not metabolized in the $\beta$-cells of the rat pancreas enough to stimulate the insulin secretion. Furthermore, it is interesting that after maltose is perfused in the isolated rat pancreas, glucose does not stimulate the insulin secretion but tolbutamide has a tendency to release the insulin from the isolated rat pancreas (Fig. 4).

Sucrose or lactose also does not have a potency enough to stimulate the insulin secretion. Our study suggests that circulating disaccharides may not stimulate the insulin secretion from the rat pancreas.

\section{References}

1) Anderson, E. \& Long, J.A. The effect of hyperglycemia on insulin secretion as determined with the isolated rat pancreas in a perfusion apparatus. Endocrinology, $1947,40,92-97$.

2) Bittencourt, H., Sleisenger, M.H. \& Weser, E. Studies of serum and tissue maltases in the rat. Gastroenterology, 1969, 57, 410-414.

3) Grodsky, G.M., Batts, A.A., Bennett, L.L., Vcella, C., McWilliams, N.B. \& Smith, D.F. Effects of carbohydrates on secretion of insulin from isolated rat pancreas. Amer. J. Physiol., 1963, 205, 638-644.

4) Morgan, C.R. \& Lazarow, A. Immunoassay of insulin using a two-antibody system. 
Proc. Soc. exp. Biol. Med., 1962, 110, 29-32.

5) Sussman, K.E., Vaughan, G.D. \& Timmer, R.F. An in vitro method for studying insulin secretion in the perfused isolated rat pancreas. Metabolism, 1966, 15, 466-476.

6) Teller, J.D. Direct, quantitative, colorimetric determination of serum or plasma glucose. Abstracts of papers, the 130th meeting, Amer. Chem. Soc., Atlantic City, N.J., Sept. 1956.

7) Weser E., Sleisenger, M.H., Dickstein, M. \& Bartley, F.H. Metabolism of circulating disaccharides in man and the rat. J. clin. Invest., 1967, 46, 499-505.

8) Young. S.J.M. \& Weser. E. Effect of insulin on the metabolism of circulating maltose. Endocrinology, 1970, 86, 426-429. 